\title{
A CRISE DE (IR)RACIONALIDADE DO SISTEMA PENAL: A DESSUBJETIVAÇÁO DO “OUTRO” NO ESTADO DE EXCEÇÃO DAS SOCIEDADES PÓS-DISCIPLINARES
}

\author{
Diogo Mariano Carvalho de Oliveira* \\ Jorge Sobral da Silva Maia**
}

SUMÁRIO: Introdução; 2 A crise do discurso jurídico penal; 3 Trabalbo imaterial, multidão e sociedades pós-disciplinares; 40 "Outro" como refugo bumano; 5 Dispositivo, "Homo Sacer" e estado de exceção; 6 A nova lógica atuarial na sociedade de risco; 7 Conclusão; Referências.

RESUMO: Existe uma constante e permanente crítica às atuais condições do sistema penal, principalmente no Brasil, sempre no sentido de afirmar que a penalidade contemporânea encontra-se em crise. No entanto, indaga-se: o sistema penal está em crise, ou ele "é crise"? Propõe-se aqui que a irracionalidade do sistema penal moderno é inerente ao seu próprio funcionamento, lógica essa determinada pela disposição dos modos de produção e as relações sociais da modernidade. Não há, portanto, nada de surpreendente na crise do sistema penal e em seus aspectos seletivos. Em verdade, a seletividade sempre foi uma imanência do sistema penal. A diferença é que hoje esse processo ocorre de maneira muito mais sutil e ideologizada e seus efeitos desencadeiam a crescente destruição identitária do "outro". O sujeito moderno encontra-se cada vez mais "dessubjetivado", e aqueles que sofrem ainda mais com os mecanismos da biopolítica são a "Multidão", lançada cada vez mais próxima à condição elementar 0 de bomini sacrii, de refugo humano, inseridos num estado de exceção que se compõe cada vez mais como estrutura jurídico-política padrão. Dessa forma, o presente trabalho tem como objetivo propor uma breve análise contemporânea crítico-filosófica do fenômeno carcerário, a fim de possibilitar a elaboração de um novo conjunto de abordagens que possa ser eficaz para tratar de maneira atual a seletividade penal, o encarceramento em massa e a ilegitimidade do discurso jurídico penal, utilizando-se como referencial teórico principal a criminologia crítica e como metodologia a dialética.

PALAVRAS-CHAVE: Crise; Multidão; Penalidade; Risco; Homo sacer.

\footnotetext{
" Mestre em Ciência Jurídica pela Universidade Estadual do Norte do Paraná (UENP), Brasil. E-mail: diogo.carvalho92@hotmail.com

** Pós-Doutor pela Universidade Estadual Paulista (UNESP), Botucatu (SP). Docente no Programa de Pós-graduação em Ciências Jurídicas e Docente Adjunto no Centro de Ciências Humanas da Universidade Estadual do Norte do Paraná (UENP), Brasil.
} 


\title{
THE CRISIS OF (IR)RATIONALITY OF THE PENAL SYSTEM: THE DE-SUBJECTIVITY OF THE 'OTHER' IN THE STATE OF EXCEPTION IN POST-DISCIPLINARY SOCIETIES
}

\begin{abstract}
There is a constant and permanent critique to current conditions of the penal system, especially in Brazil, insisting that contemporary penalty is in crisis. One may ask: Is the penal system in crisis or is it the crisis? It may be suggested that the irrationality of the modern penal system is inherent to its functioning, a logic determined by the disposition of production modes and modern social relationships. In fact, there is no surprise in the crisis of the penal system and its selective aspects. Selectivity has always been immanent to the penal system. The difference lies in the fact that the process occurs in a subtler and ideologized manner and its effects trigger the increasing identity destruction of the Other. The modern subject is more and more de-subjectified and that which most suffers within the biopolitical mechanisms is the 'multitude'. In fact, it is placed close to the elemental zero condition of bomini sacri, human waste, inserted within a state of exception increasingly composing the standard juridical and political structure. Current paper comprises a short critical and philosophical analysis of the prison phenomenon to elaborate a new set of approaches to deal with penal selectivity, mass imprisonment and the illegitimacy of the penal juridical discourse. The main theoretical reference will be critical criminology; and dialectics will be the methodology used.
\end{abstract}

KEY WORDS: Crisis; Multitude; Penalty; Risk; Homo sacer.

\section{LA CRISIS DE (IR)RACIONALIDAD DEL SISTEMA PENAL: LA DE SUBJETIVACIÓN DEL “OTRO” EN EL ESTADO DE EXCEPCIÓN DE LAS SOCIEDADES POST-DISCIPLINARES}

RESUMEN: Hay una constante y permanente crítica a las actuales condiciones del sistema penal, principalmente en Brasil, siempre en el sentido de afirmar que la penalidad contemporánea se encuentra en crisis. Sin embargo, se indaga: ¿el sistema penal está en crisis, o él "es la crisis"? Se propone aquí que la irracionalidad del sistema penal moderno es inherente a su propio funcionamiento, lógica esa determinada por la disposición de los modos de producción y las relaciones sociales de la modernidad. No hay, por lo tanto, nada de sorprendente en la crisis del sistema penal y en sus aspectos selectivos. En verdad, la selectividad siempre fue una inmanencia del sistema penal. La diferencia es que hoy ese proceso sucede de manera muy sutil e ideologizada y sus efectos desencadenan la creciente destrucción de la identidad del "otro". El sujeto moderno se encuentra cada vez más "desubjetivado", y aquellos que sufren aún más con los mecanismos de la bio política son la "Multitud", lanzada 
cada vez más cerca a la condición elementar 0 de homini sacrii, de rechazo humano, inseridos en un estado de excepción que se compone cada vez más como estructura jurídico-política patrón. De esa forma, en el presente estudio se tiene como objetivo proponer un breve análisis contemporáneo crítico-filosófica del fenómeno carcelario, a fin de posibilitar la elaboración de un nuevo conjunto de abordaje que pueda ser eficaz para tratar de manera actual la selectividad penal, el encarcelamiento en masa y la ilegitimidad del discurso jurídico penal, utilizándose, como referencial teórico principal la criminología crítica y como metodología la dialéctica.

PALABRAS CLAVE: Crisis; Multitud; Penalidad; Riesgo; Homo sacer.

\section{INTRODUÇÃO}

A penalidade disciplinar encontrou seu fim a partir das transformações ocorridas na passagem ao pós-fordismo. O cárcere deixa, assim, de exercer sua função primacial de docilização dos corpos e normalização do indivíduo; não há mais necessidade de reproduzir dentro das instituições de sequestro a ordem social burguesa ideal, já que, além da desnecessidade de mão de obra industrial de reserva - em razão da crescente relevância do trabalho imaterial e do desenvolvimento tecnológico -, o discurso fetichista do capital já não encontra significativa resistência, restando-se consolidado no imaginário social como verdade ontológica.

Um breve relance da história deixa esse aspecto claro na medida em que é possível notar no cenário político global atual a inexistência de governos que apresentem alguma efetiva oposição global ao capitalismo; a resistência ao império do capital foi eliminada juntamente com o último governo declaradamente anticapitalista - ao menos enquanto ainda conservava o legado da Revolução de Outubro ${ }^{03}$ : a União das Repúblicas Socialistas Soviéticas (URSS). A mais radical das práticas políticas de hoje acaba por se reduzir às diretrizes de uma social-democracia.

Para alguns, a partir do fim da Guerra Fria, não restaria nada à humanidade a não ser encarar o estagnacionismo da democracia liberal ocidental como solução final do mundo humano. É o que o sociólogo Francis Fukuyama veio a conceber

\footnotetext{
${ }^{03}$ Sobre a Revolução de Outubro, cf.: TRÓTSKI, Leon. A Revolução de Outubro. 2. ed. Tradução de Daniela Jinkings et al. São Paulo: Boitempo, 2017; GOMIDE, Bruno Barretto (Org.). Escritos de outubro. Paula Almeida et al. 1. ed. São Paulo: Boitempo, 2017; MIÉVILLE, China. Outubro: história da Revolução Russa. Tradução de Heci Regina Candiani. São Paulo: Boitempo, 2017; LOSURDO, Domenico. Guerra e revolução: o mundo um século após outubro de 1917. Tradução de Ana Maria Chiarini e Diego Silveira Coelho Ferreira. São Paulo: Boitempo, 2017; DORIA, Kim; JINKINGS, Ivana. 1917: o ano que abalou o mundo. São Paulo: Boitempo, 2017.
} 
como o "fim da história", ao retomar uma terminologia já cunhada anteriormente por Georg W. F. Hegel. ${ }^{04}$

"Fim da história" ou não, a oposição é necessária. As problematizações devem ser delimitadas para que a crítica possa ter lugar, e assim consiga ser adequadamente desenvolvida para que então propostas resolutórias possam ser feitas. Nesse sentido é que esse artigo se ocupará da concreticidade particular que se apresenta na dogmática penal contemporânea e para tanto será preciso deitar os olhos sobre a atual situação do discurso jurídico-penal e da penalidade, apoiando-se numa breve análise crítica e dialético-material do fenômeno penal. ${ }^{05}$

\section{A CRISE DO DISCURSO JURÍDICO-PENAL}

\section{O cárcere, a partir da modernidade e da consolidação do capitalismo, passa} a realizar uma função repressivo-ideológica de contenção e segregação seletiva de determinados estamentos sociais. Destaca-se, porém, que o fenômeno da seletividade penal não é apenas um fenômeno contemporâneo, mas constitui-se como as-

${ }^{04}$ Cf. FUKUYAMA, Francis. The end of history and the last man. Nova York, EUA: The Free Press, 1992. Todavia, cabe apontar que nos últimos anos Fukuyama tem repensado sua posição - apresentada inicialmente num artigo em 1989, que precedeu o livro "O fim da história e o último homem" - repensando se a história teria realmente acabado e se a democracia liberal teria se consolidado de maneira incontestável. Deveras, Fukuyama reconhece, por um lado, que a democracia liberal ainda não se estabeleceu de forma sólida o suficiente para corroborar a tese de que a história acabou e não haveria mais espaço para outras grandes narrativas; por outro lado, ele ainda insiste na ideia de que a democracia liberal é o caminho mais provável da humanidade como um todo. (Cf. FUKUYAMA, Francis. A história venceu: Francis Fukuyama joga a toalha. Exame, São Paulo, 22. jan. 2016. Disponível em: https://exame.abril.com.br/revista-exame/a-historia-venceu/. Acesso em: 07/12/2017; FUKUYAMA, Francis. Para filósofo, "fim da história" pode acontecer - de novo. Exame, São Paulo, 30 jun. 2016. Disponível em: https://exame.abril.com.br/economia/para-filosofo-o-fim-da-historia-pode-acontecer-de-novo/. Acesso em 07/12/2017).

${ }^{05}$ Advertimos, contudo, que a dialética não pode ser entendida propriamente como um método. A dialética não é um método, ao menos não da forma como a trabalhamos aqui, em que seu significado procure se aliar à ideia de dialética em Hegel e Marx. Ela não é um procedimento investigativo, nem existe apenas como um processo interno ao pensamento lógico; tampouco é uma forma de exposição ou de investigação. Pelo contrário, na dialética, a rigor, não há nenhum método, se tomarmos o significado da palavra como um conjunto de certas regras, padrões e linhas fundamentais tomadas a priori e a partir das quais se investiga dado objeto. Trata-se justamente do contrário, de compreender a dialética como uma antimetodologia; de concebê-la como o procedimento por meio do qual o objeto é investigado por si só em toda sua efetividade e materialidade, de modo que ele mesmo revela, ao longo do processo investigativo, suas regras e padrões. (BEISER, Frederick C. Hegel. New York, USA; London, England: Routledge, 2005, p. 159-160). Este posicionamento pode ser encontrado também em: cf. KOJÈVE, Alexandre. Introdução à leitura de Hegel. Tradução de Estela dos Santos Abreu. Rio de Janeiro: Contraponto, 2014; MENEZES, Djacir. Motivos alemães: filosofia, hegelianismo, marxologia, polêmica. Rio de Janeiro: Cátedra; Brasília, INL, 1977; NETTO, José Paulo. Introdução ao estudo do método de Marx. São Paulo: Expressão Popular; MARX, Karl. Grundrisse: manuscritos econômicos de 1857-1858: esboços da crítica da economia política. Tradução de Mário Duayer e Nélio Schneider. São Paulo: Boitempo; Rio de Janeiro: Ed. UFRJ, 2011; ROSDOSLKY, Roman. Gênese e estrutura de O Capital de Karl Marx. Tradução de César Benjamin. Rio de Janeiro: EDUERJ; Contraponto, 2001; KASHIURA JR., Celso Naoto. Crítica da igualdade jurídica: contribuição ao pensamento jurídico marxista. São Paulo: Quartier Latin, 2009. 
pecto inerente à própria sistemática penal moderna. A função real do sistema penal moderno sempre teve como objeto a administração das subclasses - inicialmente como forma de docilização dos corpos e normalização dos indivíduos - reproduzindo dentro do cárcere a ordem ideal visada pela estruturas de poder. Zaffaroni assevera que

A realidade operacional de nossos sistemas penais jamais poderá adequar-se à planificação do discurso jurídico-penal, [...] todos os sistemas penais apresentam características estruturais próprias de seu exercício de poder que cancelam o discurso jurídico-penal e que, por constituírem marcas de sua essência, não podem ser eliminadas, sem a supressão dos próprios sistemas penais. A seletividade, a reprodução da violência, a criação de condições para maiores condutas lesivas, a corrupção institucionalizada, a concentração de poder, a verticalização social e a destruição das relações horizontais ou comunitárias não são características conjunturais, mas estruturais do exercício de poder de todos os sistemas penais. ${ }^{06}$

Os aspectos deficitários do sistema penal são, portanto, aspectos que lhe são natos. Por essa razão, é preciso arguir se algum dia existiu no sistema penal moderno bases precisas que o legitimassem. É necessário, destarte, que seja descartada qualquer legitimação deontológica; a reles tentativa de legitimação moral do sistema penal escapa à realidade; a determinação dos parâmetros e limites que circundam a dogmática penal nunca incluiu qualquer dimensão moral a não ser sob um véu ideológico. Há, portanto, uma crise de legitimidade do sistema penal? Ou a crise é uma imanência própria, constante e permanente do discurso jurídico-penal?

Se essas características que demonstram deficiências fatais do sistema penal são estruturais, não é plausível falar de crise do sistema jurídico-penal. Crise é um conceito que envolve mudança, uma inflexão fenômenica que desvela uma contradição entre o discurso jurídico penal e sua operacionalidade real. Trata-se, portanto, de uma situação transitória, de maneira que seria incoerente tratar da corrente situação do sistema penal como crise. Assim, o termo crise não deve ser visto aqui sob sua acepção usual, mas como o estado da situação onde a incoerência, a irrealização e a descredibilidade do dever-ser do discurso jurídico-penal ganha magnetude tal que sua sustentação revela-se impossível. A crise não foi, não é e nem nunca será um aspecto conjuntural da dogmática penal; o discurso jurídico penal é crise.

${ }^{06}$ ZAFFARONI, Eugenio Rául. Em busca das penas perdidas: a perda da legitimidade do sistema penal. Tradução de Vania Romano Pedrosa e Amir Lopez da Conceição. Rio de Janeiro: Revan, 1991, p. 15. 
Não obstante, o sistema penal não poderia ter se mantido até aqui se não pudesse legitimar-se pelo menos por meio de malabarismos ideológicos. Essa legitimação se dá por meio de um planejamento racional do exercício de poder; é uma legitimação diferida ou postergada, pois coloca-se como uma construção teóricodiscursiva, mas sua efetiva legitimação só poderia se concretizar caso a racionalidade do discurso ideológico jurídico-penal correspondesse à efetiva prática do sistema penal.

O conceito de racionalidade deve ser entendido por meio de dois aspectos que conglobam sua totalidade: a) a racionalidade corresponde à coerência interna do discurso jurídico-penal; e b) a racionalidade corresponde à uma significação verdadeira da operatividade social ${ }^{07}$.

Para Zaffaroni, ambos esses aspectos são o que compõem a legitimidade útopica do sistema penal. Utópica, pois sua real legitimidade é inalcançável. A coerência deve ser entendida não apenas como a ausência de contradições lógicas internas, mas requer, segundo o autor, uma fundamentação antropológica lacônica, já que, se o direito deve servir ao homem, a legitimação e o exercício do poder ramificado nas confluxos do sistema penal deve conjecturar-se a partir de uma "real ontologia" do homem ${ }^{08}$. É preciso, porém, ponderar esta proposta com certa cautela, haja vista a "flexibilidade" do termo "ontológico". Na verdade, as relações do ser com si, para si e para com o exterior levanta outro problema, na medida em que a constante reprodução de discursos ideológicos e fetichistas, principalmente pelos dispositivos - no sentido agambeano - contemporâneos, acabam por embaralhar e retorcer o que poderia ser uma ontologia real do indivíduo moderno ao replicar os saberes e não saberes determinados pela lógica estabelecida. A própria busca por uma verdadeira ontologia estaria limitada e orientada pelo plano ontológico já dado pela lógica corrente; a concepção de uma nova ontologia seria então apenas possível mediante a ruptura com o paradigma da totalidade singular atual.

O discurso jurídico-penal, por consequência, não pode ser recuperado dentro das circunstâncias atuais. Zaffaroni, portanto, conclui que

O discurso jurídico-penal não pode desentender-se do "ser" e refugiar-se ou isolar-se no "dever ser" porque para que esse "dever ser" seja um "ser que ainda não é" deve considerar o vir-a-ser possível do

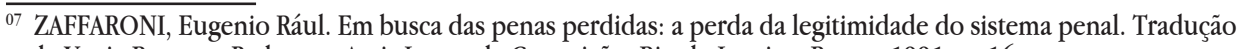
de Vania Romano Pedrosa e Amir Lopez da Conceição. Rio de Janeiro: Revan, 1991, p. 16.

${ }^{08}$ Ibidem, p. 16, 17. 
ser, pois, do contrário, converte-a em um ser que jamais será, isto é, num embuste. Portanto, o discurso jurídico penal socialmente falso também é perverso: torce-se, retorce-se, tornando alucinado um exercício de poder que oculta ou perturba a percepção do verdadeiro exercicio de poder. A quebra de racionalidade do discurso jurídico-penal arrasta consigo - como sombra inseparável - a pretendida legitimidade do exercício de poder dos órgãos de nossos sistemas penais. Atualmente, é incontestável que a racionalidade do discurso jurídico penal tradicional e a conseqüente legitimidade do sistema penal tornaram-se "utópicas" e "atemporais": não se realizarão em lugar algum e em tempo algum ${ }^{09}$.

Se o discurso jurídico-penal carece de racionalidade, se ele não corresponde ao devido ser-é, mas coloca-se como um dever-ser que deve vir-a-ser - mas que, como apontado, jamais será - ele deve munir-se de instrumentos que possam garantir ainda que minimamente a concretização desse movimento, e por essa razão é que a transgressão das normas postas correspondem diretamente à uma sanção. É claro que sua racionalidade não corresponde às necessidades reais do meio social, mas condiciona o próprio meio pela ideologia jurídica, impondo-se como uma verdade discursiva que se autolegitima por meio do seu próprio discurso e de outros saberes que são produzidos em dispositivos correlatos.

O fim último do sistema penal, logo, não é uma intervenção legitimada e justa, mas uma forma de manter a ordem social determinada pelo modo de produção estabelecido. Por essa razão, o direito penal estabelece a obrigatoriedade de condutas que devem ser conformes e consentâneas com o modo de produzir de uma sociedade. Essa garantia se dá pelo estabelecimento de sanções que protegem ou censuram determinadas condutas que desviam-se dos comportamentos exigidos ${ }^{10}$. Dessa maneira, a ideologia do direito pode impor-se, realizando a manutenção do modo de produção em interesse daqueles que compõem as classes dominantes e garantindo a consolidação de uma ordem social "perfeita".

Se de um lado a sanção garante a eficácia normativa, de outro, ela garante a sobrevivência do grupo ou grupos que ocupam o poder. Essa afirmação é feita a partir do pressuposto evidente de que o poder não legisla contra si mesmo, isto é, os grupos que detêm o controle do aparelho legiferante não vão engendrar normas que criem fissuras essenciais na ideologia que funda o ordenamento jurídico. Simplificando, os grupos do poder não normatizam contra seus próprios

${ }^{09}$ Ibidem, p. 19.

${ }^{10}$ AGUIAR, Roberto A. R. de. Direito, Poder e Opressão. São Paulo: Alfa-Ômega, 1990, p. 98. 
interesses, o que configuraria um suicídio econômico-político. Eles podem conceder no jogo pela sobrevivência, eles podem "abrir" o ordenamento dentro dos parâmetros de seus interesses, mas nunca eles legislarão contra o "espírito da lei", isto é, contra a ideologia traduzida pelo ordenamento ${ }^{11}$.

Há algumas décadas esses interesses investidos no sistema penal, principalmente no cárcere, eram vertidos por meio um mecanismo estratégico disciplinador que se constituía como um dispositivo reprodutor de processos subjetivantes - ainda que houvesse subjacentemente em seus movimentos internos um momento dessubjetivante - que reproduzia dentro do estabelecimento carcerário uma ideologia dominante no intuito de reformar seus internos, reforma essa que nada tinha a ver com ressocialização social, como propunham suas teorias justificadoras, mas que era absolutamente direcionada à reconstrução do indivíduo enquanto força-trabalho produtiva e docilizada.

Como em todos os discursos jurídicos-penais que precederam a dogmática penal moderna, a pena funciona como exercício violento de poder. A diferença do cárcere e dos suplícios no que tange aos efeitos não é, pois, tão diferente assim. $\mathrm{O}$ que os difere é que com o advento da prisão tornou-se possível revestir a pena com certo "humanitarismo" que permitiu o ocultamento de crueldade, ao mesmo tempo em que se criou um mecanismo de controle e de gestão muito mais eficaz do que aqueles que o precederam. O contraste é que a obscuridade e a perversidade da pena agora não se dão mais sob o espetáculo do suplício, mas conformam-se entre quatro paredes, afastando sua perturbadora realidade dos olhos da sociedade.

\section{TRABALHO IMATERIAL E MULTIDÃO NAS SOCIEDADES PÓS- DISCIPLINARES}

Para aventurar-se nas novas práticas e contingências do discurso penal, é necessário compreender as mudanças estruturais que acometeram o modo de produção capitalista. O novo momento pós-fordista que agora corre marca-se pela presença de um trabalho imaterial e socializado, nesse momento possível pelos avanços tecnológicos verificados com enfraquecimento do tradicional modo de produção fordista. Essa nova conjuntura do processo produtivo caracteriza-se pela socialização 
do trabalho, informatização do social e inserção de novas tecnologias de automação fabris. O trabalho material, paupável e imediatamente produtivo é retirado da centralidade do processo laboral e dá espaço para um trabalho incorpóreo produzido por uma força-trabalho intelectual ${ }^{12}$.

Esse trabalho imaterial deve ser entendido como o complexo de atividades intelectuais, afetuosas e comunicativas exprimidas pelos movimentos sociais e pelos sujeitos. No pós-fordismo a produtividade passa a depender fundamentalmente das energias científicas e culturais que o formam; essa reorganização vem a destruir as condições efetivas nas quais a acumulação de capital previamente se fundamenta$\mathrm{va}^{13}$ :

Na produção pós-fordista, a linguagem tornou-se, ela mesma, uma força produtiva. Todo aparato de signos foi confiado à criatividade do trabalho vivo: isto é o que constitui a forma criadora dominante em nossa sociedade. Trabalha-se com linguagem e constrói-se com signos. Neste ponto, controle dos sentidos e significado dos signos, linguagens e sistema produtivos são algo que excede qualquer nexo linear possível e, portanto, qualquer controle absoluto ou unilateral. [...] O campo criativo do significado corrói a possibilidade de um controle absoluto sobre as linguagens ${ }^{14}$.

É possível afirmar que agora a produtividade não se restringe apenas ao espaço fabril, pois a produção de valor não exige mais a imersão da força-trabalho dentro do espaço delimitado do emprego; nas circunscrições do "não trabalho" há agora também um processo produtivo de valor, já que a criação de capital não se restringe mais apenas à esfera da criação material, estendendo-se também como produto de uma intelectualidade resultante das redes relacionais cooperativas e produtoras de uma imaterialidade linguística.

O trabalho se torna lingüístico na medida em que a comunicação se torna mercadoria (sob a forma da mercadoria-informação) e o intelecto, entendido como conjunto de faculdades comunicativas, expressivas e inventivas, torna-se o novo utensílio da produção pós-fordista. Assim, os tempos e lugares que na sociedade-fábrica separavam o universo da produção da esfera da reprodução são desestruturados: o trabalho progressivamente retira-se do perímetro da instituição fechada. Nesse sentido, torna-se cada vez mais problemática uma real

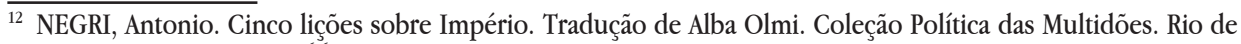
Janeiro: DP\&A, 2003, p. 66.

${ }_{13}^{13}$ Ibidem, p. 92.

${ }^{14}$ Ibidem, p. 81.
} 
separação entre tempo de trabalho e tempo de não-trabalho. De um lado, na realidade, o tempo de reprodução da força de trabalho imaterial torna-se tempo diretamente produtivo, uma vez que a empresa pós-fordista confere valor a competências, habilidades, atitudes que se desenvolvem (ou melhor, que se constituem) sobretudo durante o tempo de "não trabalho". Por outro lado, o trabalho imaterial se caracteriza exatamente como processo de produção daquelas relações lingüísticas e comunicativas nas quais se desenvolvem competências, habilidades e atitudes a serem valorizadas ${ }^{15}$.

O trabalho é, portanto, resultado da própria atividade humana; na verdade, são as subjetividades humanas que irão constituir uma nova espécie de trabalho que se valoriza pela própria produção daquilo que é reproduzido no meio social. As capacidades humanas de criação, de linguagem, de comunicação e expressão criam valor, ao mesmo tempo que o reproduzem nas relações humanas. Se antes a produção de valor por meio do trabalho era somente possível pela criação material dentro de um processo produtivo industrial, agora ela é possível também fora dele.

Um dos exemplos desse fenômeno pode ser representado pelo logo comercial. Nos novos rearranjos produtivos do pós-fordismo marcados pelos signos, o logo não se reduz a uma mera marca que possibilita a distinção de um produto por outro de origem diversa. $\mathrm{O}$ logo, de fato, enceta em si o valor imaterial e lingüístico do próprio produto, fazendo dele um meio de comunicação social enquanto parte de um estilo de vida; o logo encerra em si uma experiência de relações, nas quais veicula e produz subjetividades; mas ele mesmo é concomitantemente resultado de uma valorização de subjetividades, que são reproduzidas nas próprias relações que se compõem entre os sujeitos e nas redes de comunicação, e esse fluxo de linguagens e símbolos que são veículados na comunicação são transformados em mercadoria enquanto elementos constitutivos de valor ${ }^{16}$.

Nesse ínterim, considerando os novos aspectos da imaterialidade do trabalho e da produtividade dentro dos espaços do não trabalho, há portanto um novo problema a ser enfrentado pelas instituições penais. Se no fordismo o regime de produção era caracterizado pela carência de mão de obra adequada, e portanto, orientavam-se estratégias no sentido de disciplinamento da carência, com o despontar do pós-fordismo o regime produtivo é de excesso, de forma que não há interesse nesse disciplinamento, essencialmente por questões lógicas de mercado.

\footnotetext{
${ }^{15}$ GIORGI, Alessandro De. A miséria governada através do sistema penal. Tradução de Sérgio Lamarão. Rio de Janeiro: Revan, 2006, p. 72, 73.

${ }^{16}$ NEGRI, Antonio. Op. cit., p 73-74.
} 
O que se verifica é a presença de dois aspectos diversos desse excesso, que implicarão na modificação dos mecanismos de controle social. A quantidade de mão de obra disponível enseja assim a formação de um excesso negativo ou fordista e um excesso positivo ou pós-fordista.

Isso nos coloca diante de uma ruptura com a ideia de sociedade disciplinar proposta por Foucault; em "Vigiar e Punir", Foucault demonstra a paulatina transformação das instituições carcerárias e de internação - algo abordado, em certa medida, por Erving Goffman em "Prisões, manicômios e conventos" - e como elas reproduzem e replicam um esquema crescente de disciplina e esquadrinhamento do corpo submetido às relações de poder intrainstitucionais, sob o escopo de torná-lo dócil, domesticado e produtivo, por meio das disciplinas ${ }^{17}$.

As disciplinas, organizando as "celas", os "lugares" e as "fileiras" criam espaços complexos: ao mesmo tempo arquiteturais, funcionais e hierárquicos. São espaços que realizam a fixação e permitem a circulação; recortam segmentos individuais e estabelecem ligações operatórios; marcam lugares e indicam valores; garantem a obediência dos indivíduos, mas também uma melhor economia do tempo e dos gestos. São espaços mistos: reais, pois que regem a disposição dos edifícios, de salas, de móveis, mas ideias, pois projetam-se sobre essa organização caracterizações, estimativas, hierarquias. A primeira das grandes operações da disciplina é então a constituição de "quadros" vivos que transformam as multidões confusas, inúteis ou perigosas em multiplicidades organizadas. ${ }^{18}$

Essa edificação "burguesa" do corpo no cárcere, na fábrica, no quartel, no hospital ou mesmo na família somente pode ser compreendida se considerada como parte da sistematização do trabalho que necessita organizar o corpo como aparato no interior do engenho produtivo. Para que se possa compreender a construção burguesa do corpo, é premente entender que no capitalismo a organização do trabalho incorpora o corpo na cadeia produtiva; o corpo não é um objeto estranho à rede produtiva, é considerado parte dela; ele é estruturado de forma sincrônica e canora com o processo de produção, sendo entabulado como força de trabalho. Os maquinários da produção, assim, compõem-se em parte por uma estrutura anorgânica, fixa e estável, e em parte por um composto vivo, orgânico e variável. ${ }^{19}$

\footnotetext{
${ }^{17}$ Cf. GOFFMAN, Erving. Prisões, manicômios e conventos. Tradução de Duarte Moreira Leite. São Paulo: Editora Perspectiva, 1974.

${ }^{18}$ FOUCAULT, Michel. Vigiar e punir: nascimento da prisão. Tradução de Raquel Ramalhete. 38. ed. Rio de Janeiro: Vozes, 2010, p. 215, 216.

${ }^{19}$ MASSIMO, Pavarini; MELOSSI, Dario. Cárcere e fábrica: as origens do sistema penitenciário (séculos XVI-XIX). Tradução de Sérgio Lamarão. Rio de Janeiro: Revan, 2006, p. 215, 216.
} 
Todavia, o trabalho imaterial deflagra a deslocalização produtiva, a descentralização da produção e a terciarização do trabalho, que desestruturam a forçatrabalho operária, decompondo-a em multiplicidade de trabalhadores atípicos ${ }^{20} ; 0$ trabalho - como processo de produção de valor - agora se insere tanto no espaço maquinizado do emprego quanto do não emprego, entendendo-se aquele como medida de cidadania e inclusão social. Há, nesse sentido, também a modificação semântica do conceito de desemprego, condição estrutural de um pós-fordismo marcado pelo excesso de produtividade.

O desemprego deixa, de fato, de ser associável à ideia de "inatividade" para se tornar uma medida oficial da fratura entre as inumeráveis "atividades" produtivas - isto é, aquelas que remetem à noção de trabalho no sentido próprio do termo -, nas quais os indivíduos estão continuamente envolvidos, e o limite imposto pelo sistema capitalista, a fim de de que seja reconhecido a essas atividades o valor social de "trabalho". Em outros termos, o desemprego se configura como margem de excesso da produtividade social em relação à separação artificial entre trabalho e emprego imposta pelo domínio capitalista à sociedade contemporânea. [...] O trabalho, entendido como um conjunto de ações, performances e prestações produtivas estende-se cada vez mais até integrar toda a existência social. Aquilo que experimentamos, efetivamente, é uma radical separação do trabalho, assim concebido, de um sistema de governo dos direitos e da cidadania profundamente ligado ao conceito fordista de emprego $0^{21}$.

\section{Ora, se o trabalho imaterial está pautado em uma produtividade linguística} que produz mercadoria e, consequentemente, valor, por meio do intelecto e do devir

${ }^{20}$ Como explica Harvey: "A profunda recessão de 1973, exacerbada pelo choque do petróleo, evidentemente retirou o mundo capitalista do sufocante torpor da "estagflação" (estagnação da produção de bens e alta inflação de preços) e pôs em movimento um conjunto de processos que solaparam o compromisso fordista. Em consequência, as décadas de 70 e 80 foram um conturbado período de reestruturação econômica e de reajustamento social e político [...]. No espaço social criado por todas essas oscilações e incertezas, uma série de novas experiências nos domínios da organização industrial e da vida social e política começou a tomar forma. Essas experiências podem representar os primeiros ímpetos da passagem para um regime de acumulação inteiramente novo, associado com um sistema de regulamentação política e social bem distinta". (HARVEY, David. A condição pós-moderna: uma pesquisa sobre as origens da mudança cultural. Tradução de Adail Ubirajara Sobral e Maria Stela Gonçalves. São Paulo: Edições Loyola, 1992, p.140). Essa superação do modelo fordista resultou no que Harvey descreveu como a consolidação de um novo tipo de regime de acumulação; um regime de acumulação flexível: "A acumulação flexível [...] é marcada por um confronto direto com a rigidez do fordismo. Ela se apoia na flexibilidade dos processos de trabalho, dos mercados de trabalho, dos produtos e padrões de consumo. Caracteriza-se pelo surgimento de setores de produção inteiramente novos, novas maneiras de fornecimento de serviços financeiros, novos mercados e, sobretudo, taxas altamente intensificadas de inovação comercial, tecnológica e organizacional. [Mas] a acumulação flexível parece implicar níveis relativamente altos de desemprego "estrutural" (em oposição a "friccional"), rápida destruição e reconstrução de habilidades, ganhos modestos (quando há) de salários reais [...] e o retrocesso do poder sindical - uma das colunas políticas do regime fordista." (Ibidem, p. 140, 141).

${ }^{21}$ GIORGI, Alessandro De. Op. cit., p. 72-73. 
comunicativo, essa produtividade já não se restringe mais às delimitações espaciais das grandes indústrias e do emprego, sendo reproduzida também nas condições do não emprego. Não há carência de produtividade, e por essa razão tampouco há carência de uma mão de obra adequada, pois agora a própria vida submete-se ao trabalho. Mas se o trabalho impõe-se como pressuposto para a manuntenção do status de cidadão, prefigura-se uma nova categoria de indivíduos que estão completamente excluídos da esfera do trabalho conforme compreendido no contexto fordista.

O desemprego, a marginalidade e a exclusão social constituem aspectos desse excesso negativo na medida em que se observa que as condições de inclusão social são quantificadas pelo trabalho enquanto emprego, entendendo-se este como ocupação em tempo integral, garantida, estável e contínua, de tal forma que a condição de cidadão está intimamente subordinada à capacidade de ser trabalhador. Ao mesmo tempo a reestruturação das relações de produção pós-fordista fundam-se exatamente na redução e na precarização do trabalho ${ }^{22}$.

Sincronicamente, forma-se também um excesso positivo, já que o pós-fordismo tipifica-se essencialmente pela inclusão e centralização do trabalho imaterial como produção e reprodução de valor. O excesso pós-fordista

Configura-se aqui como excesso constante de potencialidades produtivas, de laços de cooperação, de formas da comunicação com respeito às geografias da produção impostas por uma racionalidade capitalista reduzida ao domínio. O capital - não mais em condições de governar ativamente, a partir de dentro, a produtividade social, visto que esta excede as formas capitalistas de racionalização do real - limita-se a exercer um controle, a expressar-se como puro limite externo em relação a uma cooperação produtiva que prefigura sua obsolescência ${ }^{23}$.

Deslindam-se, portanto, dois aspectos do regime de excesso introduzido pelo pós-fordismo. Por um lado, verifica-se a representação do excesso negativo como conjunto de subjetividades que extrapolam a razão governamental, uma vez que ressaltam a contradição entre uma esfera produtiva cada vez menos carente de trabalho vivo e uma cidadania social ainda assentada sobre o trabalho, ao passo que o excesso positivo é marcado por um complexo de subjetividades que transpõe a racionalidade capitalista na medida em que afiam uma contradição estabelecida entre uma potencialidade produtiva absoluta e cooperativa e uma ordenação das relações

\footnotetext{
${ }^{22}$ Ibidem, p. 90.

23 Ibidem, p. 76.
} 
de produção que contitui um embaraço à soberania do comando capitalista, obrigando às relações de produção uma acumulação de valor baseada na competição ${ }^{24}$.

O que se verifica então é a formação de uma multiplicidade abstrusa de subjetividades singulares que constantemente produzem e reproduzem valor em meio aos emaranhados cooperativos das relações sociais e que ao mesmo tempo escapam das redes de dominação do capital. Esse complexo de individualidades forma uma multidão que, consoante extrapolem a razão governamental por escaparem à regulamentação do capital, também encetam a necessidade de novos mecanismos de controle pós-disciplinar, já que constituem uma estrutura multíplice não representável alocada fora dos terrenos do trabalho-emprego, elemento pressuposto de cidadania.

Para compreender esse conceito proposto por Antonio Negri é preciso salientar que a multidão deve ser compreendida sob quatro aspectos: 1) a multidão deve ser entendida como um conjunto de individualidades, ou seja, como multiplicidade de subjetividades ou singularidades; 2) a multidão também deve ser encarada como classe social não operária, levando-se em consideração a passagem do fordismo ao pós-fordismo e da presença hegemônica do trabalho imaterial em detrimento do trabalho material; 3) a multidão não é uma multiplicidade reduzível ao conceito de massa por ser capaz de desenvolver-se intelectualmente de forma autônoma e independente; 4) a multidão é um universal concreto sem representação, estabelendo-se em contraste com o conceito de povo, unidade representativa e constituinte do corpo social ${ }^{25}$. Mas o que notavelmente se constitui como característica desse novo personagem da totalidade concreta corrente é que

Multidão indica, sobretudo, a impossibilidade de uma reductio ad unum das diversas subjetividades produtivas comparáveis àquela que pemitiria individualizar, na classe operária, a forma de subjetividade hegemônica durante a época do capitalismo fordista ${ }^{26}$.

Mas com o surgimento dessa multidão, como será possível a manutenção da ideologia hegemônica capitalista em face dessa nova figura multifacetada e não representável? A lógica de dominação capitalista já não pode mais ser impressa na domesticação e adequação dos corpos; o poder disciplinar inserido na prisão enceta em si sua própria obsolescência. A multidão e o regime desses excessos irão exigir

\footnotetext{
${ }^{24}$ Ibidem, p. 90.

${ }^{25}$ NEGRI, Antonio. Cinco lições sobre Império. Tradução de Alba Olmi. Coleção Política das Multidões. Rio de Janeiro: DP\&A, 2003, p. 145, 146, 166.

${ }^{26}$ GIORGI, Alessandro De. Op. cit., p. 31.
} 
novos mecanismos de controle pós-disciplinar nesse corrente cenário marcado pela abundância de produtividade e de uma mão de obra destituída dos pressupostos necessários à cidadania.

[Agora] é o capital que se mostra carente em relação a uma força de trabalho tornada flexível, nômade, móvel: multidão. A multidão produtiva excede as relações de produção capitalistas no momento em que vive diretamente a inadequação do conceito de trabalho-emprego e experimenta em si mesma a violenta negação dos direitos de cidadania provocada por esta inadequação. Nesse sentido, podemos falar aqui de um excesso negativo, evidenciando, por um lado, os efeitos da exclusão, da violência do poder e do controle que este excesso determina sobre a força de trabalho e, por outro lado, o fato de que, neste processo, o domínio do capital resulta potencialmente negado $^{27}$.

A sociedade disciplinar observa assim o seu desfecho. A disciplinaridade somente pôde ser compreendida enquanto parte da gênese do capitalismo até o modelo fordista. Os mecanismos de tecnologia disciplinar devem agora dar espaço para uma nova estruturação de controle biopolítico.

Nesse sentido, poderíamos apontar aqui ao menos três novos paradigmas da sociabilidade moderna - que não necessariamente se excluem, mas podem ser contemplados como conectados na forma de um nó borromeano ${ }^{28}$, convergindo e integrando-se dialeticamente - que superam o paradigma da sociedade disciplinar e nos colocam diante da necessidade de novas abordagens teóricas e práticas da totalidade em geral e dos efeitos que são por ela e nela produzidos, principalmente no campo da biopolítica: a sociedade de controle, a sociedade do desempenbo e a sociedade do espetáculo.

O primeiro paradigma, a sociedade de controle, é articulado por meio de um pequeno, mas importantíssimo texto escrito por Gilles Deleuze, publicado na revista L'Autre Journal, n. ${ }^{\circ} 1$ em 1990 e posteriormente integrado à obra "Conversações". Nele, Deleuze descreve rapidamente como Foucault situou as sociedades dis-

${ }^{27}$ Ibidem, p. 70,71.

${ }^{28} \mathrm{O}$ nó borromeano é uma figura da topologia matemática representado pelo desenho de três círculos interconectados de forma absolutamente dependente, de modo que o desfazimento de um dos círculos resulta no desmonte dos outros dois. É uma estrutura topológica que, por sua peculiaridade, acabou sendo importada para a psicanálise por Jacques Lacan, e depois para a filosofia por alguns autores, dentre eles Slavoj Zizek e Kojin Karatani: cf. LACAN, Jacques. O seminário, livro 23: o sinthoma (1975-1976). Tradução de Sergio Laia. Rio de Janeiro: Jorge Zahar ed. 2007; cf. ZIZEK, Slavoj. The sublime object of ideology. Londres, Inglaterra; Nova York, EUA: Verso Books, 2008; KARATANI, Kojin. Structure of world history: from modes of production to modes of exchange. Traduzido por Michael K. Bourdaghs. Durham; Londres: Duke University Press, 2014. 
ciplinares ao longo dos sécs. XVIII, XIX e XX, mas como ele também sabia que este modelo em breve seria substituído por um modelo de sociedade com objetivos e funcionamentos completamente diferentes da sociedade disciplinar, principalmente após a Segunda Guerra mundial; a partir daqui, Deleuze afirma que nós deixamos de ser sociedades disciplinares; as sociedades disciplinares foram substituídas pelas sociedades de controle. ${ }^{29}$

Diferentemente dos dispositivos disciplinares que produziam um processo de moldagem resoluta do sujeito, os controle são uma modulação, uma transformação contínua e autodeformante do sujeito. Nas sociedades de disciplina, o recomeço é constante (vai-se da casa à escola, da escola à fábrica); nas sociedades de controle o fim nunca é visto, a modulação é um efeito universal infinito, onde a empresa, a formação e o serviço são estados metaestáveis e coexistentes numa mesma cadeia de modulação. Na sociedade disciplinar, os polos fundamentais de separação e adequação são massa e individuo; nas sociedades de controle, não há incompatibilidade entre os termos, de modo que os indivíduos são prontamente divisíveis, e a massa se torna dado, amostras, mercados ou bancos. Se o homem da disciplina era um produtor intermitente de energia (ou valor), o homem do controle funciona em órbita, numa frequência ondulatória, em produção contínua. Ainda, talvez como aspecto mais distintivo, nas sociedades da disciplina o capitalismo funcionava como regime de concentração, de produção e de propriedade; nas sociedades de controle atuais o capitalismo é dirigido pela acumulação irracional; o capitalismo é de sobreprodução, vendem-se serviços, compram-se ações. O prius da produtividade capitalista das sociedades de controle é a produção, e não o produto. ${ }^{30}$

O segundo paradigma, a sociedade do desempenho, é brevemente exposto

\footnotetext{
${ }^{29}$ DELEUZE, Gilles. Post-scriptum sobre as sociedades de controle in: Conversações. Tradução de Peter Pál Pebart. São Paulo: Ed. 34, 1992, p. 219-220. Como ressalta Deleuze: "Encontramo-nos numa crise generalizada de todos os meios de confinamento, prisão, hospital, fábrica, escola, família. A família é um 'interior', em crise como qualquer outro interior, escolar, profissional, etc. Os ministros competentes não param de anunciar reformas supostamente necessárias. Reformar a escola, reformar a indústria, o hospital, o exército, a prisão; mas todos sabem que essas instituições estão condenadas, num prazo mais ou menos longo. Trata-se apenas de gerir sua agoniza e ocupar as pessoas, até a instalação das novas forças que se anunciam. São as sociedades de controle que estão substituindo as sociedades disciplinares. 'Controle' é o nome que Burroughs propõe para designar o novo monstro, e que Foucault reconhece como nosso futuro próximo. Paul Virilio também analisa sem parar as formas ultrapassadas de controle ao ar livre, que substituem as antigas disciplinas que operavam na duração de um sistema fechado. Não cabe invocar produções farmacêuticas extraordinárias, formações nucleares, manipulações genéticas, ainda que elas sejam destinadas a intervir no novo processo. Não se deve perguntar qual é o regime mais duro, ou o mais tolerável, pois é em cada um deles que se enfrentam as liberações e as sujeições. Por exemplo, na crise do hospital como meio de confinamento, a setorização, os hospitais-dia, o atendimento a domicílio puderam marcar de início novas liberdades, mas também passaram a integrar mecanismos de controle que rivalizam com os mais duros confinamentos. Não cabe temer ou esperar, mas buscar novas armas." (Ibidem, p. 220).

${ }^{30}$ Ibidem, p. 221-223.
} 
por Byung-Chul Han em "A sociedade do cansaço". Segundo o teórico cultural, também para ele as sociedades disciplinares concebidas por Foucault não são mais o modelo de sociedade atual; esse modelo foi substituído pela sociedade do desempenho, formada por sujeitos de desempenho e produção. Aliás, para Han, esse modelo teria superado até mesmo a sociedade de controle descrita por Deleuze. Na sociedade do desempenho, o elemento fundamental é a substituição da disciplina pelo desempenho, isto é, por um esquema não mais negativo, mas positivo de poder, que incentivaria maior crescimento; o sujeito do desempenho é mais produtivo e mais veloz que o sujeito da obediência. A disciplina ainda existe, mas é autoimposta; o sujeito do desempenho deve ser disciplinado por meio de uma iniciativa pessoal; trata-se de uma autocastração, a pressão pelo desempenho e o imperativo de obedecer somente a si mesmo. É o retrato ideal do autoempreendedor moderno, que se submete às autoexigências do desempenho e ao excesso do trabalho numa espiral ascendente de autoexploração e esgotamento neuronal. ${ }^{31}$

O terceiro paradigma, a sociedade do espetáculo, apresenta-se a nós por meio da obra seminal de Guy Debord - inaugurador da efêmera Internacional Situacionista -, "A sociedade do espetáculo". Nele, Debord nos revela, numa leitura atualíssima, os elementos contemporâneos peculiares da sociedade capitalista; o que era vivido diretamente, agora é conhecido apenas pela representação imagética experiencial. A sociedade se transformou num grande acúmulo de espetáculos, resultado do modo de produção capitalista que se consolidou num funcionamento fugaz de reprodução de relações sócias mediadas por imagens e cuja única finalidade é a produção, o acúmulo e o consumo de imagens; seu fim, portanto, não é nada; o desenrolar da experiência performática das imagens é tudo. O espetáculo é o projeto e o resultado do modo de produção existente, o capital em grau acumulado, o capital

\footnotetext{
${ }^{31}$ BYUNG-CHUL, Han. Sociedade do cansaço. Tradução de Enio Paulo Giachini. Petrópolis, RJ: Vozes, 2015, p. 23-30. Sob essa perspectiva, destacamos sintética passagem da posição de Byung-Chul Han: "A sociedade disciplinar de Foucault, feita de hospitais, asilos, presídios, quartéis e fábricas, não é mais a sociedade de hoje. Em seu lugar, há muito tempo, entrou uma outra sociedade, a saber, uma sociedade de academias de fitness, prédios de escritórios, bancos, aeroportos, shoppings centers e laboratórios de genética. A sociedade do século XXI não é mais a sociedade disciplinar, mas uma sociedade de desempenho. Também seus habitantes não se chamam mais "sujeitos da obediência", mas sujeitos de desempenho e produção. São empresários de si mesmos,. Nesse sentido, aqueles muros das instituições disciplinares, que delimitam os espaços entre o normal e o anormal, se tornaram arcaicos. A analítica do poder de Foucault não pode descrever as modificações psíquicas e topológicas que se realizaram com a mudança da sociedade disciplinar para a sociedade do desempenho. (Ibidem, p. 23, 24).
} 
tornado imagem, o momento em que toda a vida social é ocupada pela mercadoria. ${ }^{32}$ No tempo do espetáculo a própria vida submergiu sob as produções imagéticas das representações espetaculares. Hoje o poder espetacular não age apenas de maneira concentrada, sob o manejo de uma figura na potência do nome próprio ou de uma ideologia clara, nem simplesmente de maneira difusa, por meio de múltiplos e esparsos dispositivos, objetos e comportamentos produzidos no tempo espetacular. Ele age de modo integrado; ao irradiar toda a realidade, o espetáculo confundiu-se com ela. O devir da falsificação da vida é também o devir da vida falsificada. A cultura, a arte, a natureza e a ciência, a partir da incidência inevitável do poder espetacular integrado, estão cada vez mais submissas às forças dominantes da sociedade; isto é, encontram-se cada vez mais submetidas à circulação espetacular da razão mercantil. ${ }^{33}$

Esses novos paradigmas da sociabilidade contemporânea nos colocam diante da necessidade de uma nova análise dos mecanismos de reprodução e consolidação social, já que fundam uma nova configuração ontológica e social que, inevitavelmente, nos obriga dialeticamente a adequar materialmente o instrumental de investigação utilizado para uma efetiva observação e concepção do discurso e da prática penal atual, de modo a nos colocar diante não mais de dispositivos e mecanismos simplesmente disciplinares e domesticadores, mas de elementos pós-disciplinares próprios da gestão governamental da multidão direcionados ao controle de risco e à manutenção da intensa reprodutibilidade do capital.

\section{0 "OUTRO" COMO REFUGO HUMANO}

32 DEBORD, Guy. A sociedade do espetáculo. Tradução de Estela do Santos Abreu. Rio de Janeiro: Contraponto, 1997, p. 13-19. Destacamos ainda um excerto preciso do aforismo n. ${ }^{\circ} 42$ : "O espetáculo é o momento em que a mercadoria ocupou totalmente a vida social. Não apenas a relação com a mercadoria é visível, mas não se consegue ver nada além dela: o mundo que se vê é o seu mundo. A produção econômica espalha, extensa e intensivamente, sua ditadura. Nos lugares menos industrializados, seu reino já está presente em algumas mercadorias célebres e sob a forma de dominação imperialista pelas zonas que lideram o desenvolvimento da produtividade. Nessas zonas avançadas, o espaço social é invadido pela superposição contínua de camadas geológicas de mercadorias. Nesse ponto da "segunda revolução industrial", o consumo alienado torna-se para as massas um dever suplementar à produção alienada. Todo trabalho vendido de uma sociedade se torna globalmente a mercadoria total, cujo ciclo deve prosseguir. Para conseguir isso, é preciso que essa mercadoria total retorne fragmentadamente ao indivíduo fragmentado, absolutamente separado das forças produtivas que operam como um conjunto." (Ibidem, p. 30, 31).

${ }^{33}$ Nesse sentido, afirma Debord: "Na fase primitiva da acumulação capitalista, a economia política só vê no proletário o operário', que deve receber o mínimo indispensável para conservar sua força de trabalho; jamais o considera 'em seus lazeres, em sua humanidade'. Esse ponto de vista da classe dominante se inverte assim que o grau de abundância atingido na produção das mercadorias exige uma colaboração a mais por parte do operário. Subitamente lavado do absoluto desprezo com que é tratado em todas as formas de organização e controle da produção, ele continua a existir fora dessa produção, aparentemente tratado como adulto, com uma amabilidade forçada, sob o disfarce de consumidor. Então, o humanismo da mercadoria se encarrega dos 'lazeres e da humanidade' do trabalhador, simplesmente porque agora a economia política pode e deve dominar essas esferas como economia política. Assim, 'a negação total do homem' assumiu a totalidade da existência humana." (DEBORD, Guy. A sociedade do espetáculo. Tradução de Estela do Santos Abreu. Rio de Janeiro: Contraponto, 1997, p. 31, 32). 
Como apontado, a partir da década de 1970, com o advento lógico do pósfordismo, deflagrou-se o fim dos estratagemas disciplinares que eram impingidos dentro do cárcere. A desnecessidade de continuar a reproduzir ativamente dentro do cárcere um ideário disciplinar capitalista acabou por resultar numa espécie de "esvaziamento" do conteúdo da penalidade carcerária. Não que a prisão tenha se tornado completamente inútil e perdido seu propósito; o fato é que agora a instituição penintenciária não guarda nenhuma função específica enquanto dispositivo subjetivante como ocorria antes. Na verdade, a prisão transmuta-se agora em uma estrutura de mera contenção espaço-temporal de indíviduos "indesejados", de exclusão daqueles - parte da multidão, os possíveis bomini sacrii - que não possuem lugar na fluidez desse novo mundo regido sob o império do capitalismo globalizado

A transição da modernidade à modernidade recente pode ser vista como um movimento que se dá de uma sociedade inclusiva para uma sociedade excludente. Isto é, de uma sociedade cuja tônica estava na assimilação e na incorporação para uma que separa e exclui. Esta erosão do mundo inclusivo do período modernista [...] envolveu processos de desintegração tanto na esfera da comunidade (aumento do individualismo) como naquela do trabalho (transformação do mercado de trabalho). Ambos os processos resultam de forças de mercado e sua transformação pelos atores humanos envolvidos ${ }^{34}$.

Mas qual é o critério essencial que se estabelece hoje e que orienta o alcance e o limite desta exclusão? Quem são os excluídos, o excesso negativo dessa multidão, esse refugo humano sem lugar, os homini sacrii modernos?

Se o capitalismo globalizado reproduz-se basicamente pela produção, circulação e troca de mercadorias, serviços (e imagens!), esses movimentos requerem um uso finalístico. Uma mercadoria ou serviço apenas pode ter seu valor de troca aferido se possuir valor de uso, e esse uso apenas existe quando a mercadoria é de utilidade para alguém. É preciso, portanto, que a mercadoria seja produzida por alguém, mas que seja também desejada por outro alguém; que este alguém tenha interesse em adquiri-la e consumi-la. O consumo ou a possibilidade de consumir é, portanto, o que determina quem está incluído e quem está excluído, pois sem o consumo não há circulação de bens, sem a circulação de bens o trabalho perde sua razão de existir, sem trabalho não há sobre-trabalho, e sem sobre-trabalho não há

34 YOUNG, Jock. A sociedade excludente: exclusão social, criminalidade e diferença na modernidade recente. Tradução de Renato Aguiar. Rio de Janeiro: Revan, 2002, p. 23. 
mais-valor. O consumo é, sob esse ângulo, um fenômeno axial do modo de produção capitalista, medular para a sua permanência.

O que resta fazer àqueles que não podem consumir, ou que não podem ser reinseridos e realocados no mercado de consumo é apenas a exclusão. Esse refugo humano sem lugar deve ser excluído e separado da sociedade para que não "contamine" a ordem social; devem ser neutralizados; incluídos na ordem social para que então possam ser excluídos, assim como os bomini sacri. Nesse sentido, Bauman afirma que

O "refugo humano" não pode mais ser removido para depósitos de lixo distantes e fixados firmemente fora dos limites da "vida normal". Precisa, assim, ser lacrado em contêineres fechados com rigor. O sistema penal fornece esses contêineres. [....] as prisões, que, na era da reciclagem, "funcionavam como extremidade do setor correcional", hoje são "concebidas de modo muito mais explícito como um mecanismo de exclusão e controle". São os muros, e não o que acontece dentro deles, que "agora são vistos como o elemento mais importante e valioso da instituição". Na melhor das hipóteses, a intenção de "reabilitar", "reformar", "reeducar" e devolver a ovelha desgarrada ao rebanho é ocasionalmente louvada da boca pra fora - e, quando isso acontece, se contrapõe ao coro raivoso clamando por sangue, com os principais tabloides no papel de maestros e a liderança política fazendo todos os solos. De forma explícita, o principal e talvez único propósito das prisões não é ser apenas um depósito de lixo qualquer, mas o depósito final, definitivo ${ }^{35}$.

Eis, pois, o papel moderno da prisão. O espaço carcerário deve servir apenas como arquiteturização contencional; a função da prisão é separar aquilo que é "inútil" para a manutenção do modo de produção e da ordem social. Já não importa mais se existe qualquer espécie de trabalho carcerário como forma de recuperação de preso, e tampouco se existem formas efetivas de reestruturação subjetiva do preso. A única função necessária do espaço carcerário é aquela que se revela como meio de sua contenção espaço-temporal. Não há e nem deve haver "salvação". Os que pouco ou nada tem a contribuir para a solidificação do modo de produção capitalista e a manutenção da exploração são sobras colaterais, indivíduos sobressalentes. Qualquer obstáculo à perpetuação da totalidade singular capitalista deve ser descartado.

Em suma, as prisões, como tantas outras instituições sociais, passa-

35 BAUMAN, Zygmunt. Vidas desperdiçadas. Tradução de Carlos Alberto Medeiros. Rio de Janeiro: Zahar, 2005, p. 108. 
ram da tarefa de reciclagem para a de depósito de lixo. Foram realocadas para a linha de frente a fim de resolver a crise que atingiu a indústria da remoção do lixo, em consequência do triunfo global da modernidade e da nova plenitude do planeta. Todo lixo é em potencial venenoso - ou pelo menos, definido como lixo, está destinado a ser contagioso e perturbador da ordem adequada das coisas. Se reciclar não é mais lucrativo, e suas chances (ao menos no ambiente atual) não são mais realistas, a maneira certa de lidar com o lixo é acelerar a "biodegração" e decomposição, ao mesmo tempo isolando-o, do modo mais seguro possível, do hábitat humano comum"36.

O isolamento desse refugo humano se torna, assim, a melhor forma de lidar com esses "restos". A separação espacial constitui-se como função essencial desse isolamento, em que se torna possível comprimir, reduzir e diminuir a visão do outro. As particularidades e casualidades individuais que se inclinam a tornarem-se perceptíveis graças à experimentação reunida pelo convívio diário dificilmente podem ser vistas quando o intercâmbio é proibido ou definha. As categorias legais acabam por subjugar e desconsiderar as diferenças, impedindo o reconhecimento do outro. Dessa forma a caracterização formal do indivíduo substitui a intimidade pessoal e a singularidade dos casos e das pessoas tornam-se desprezíveis ${ }^{37}$.

O outro - lançado numa condição de forçada estranheza, guardado e cultivado pelas fronteiras espaciais estritamente vigiadas, mantido à distância e impedido de ter um acesso comunicativo regular ou esporádico - é além disso mantido na categoria de estranho, efetivamente despojado da singularidade individual, pessoal, a única coisa que poderia impedir a esterotipagem e assim contrabalançar ou mitigar o impacto subjulgador da lei - também da lei criminal ${ }^{38}$.

Os "outros" são, assim, aqueles que não foram capazes de alcançar os padrões de consumo exigidos pelo mercado. São consumidores insatisfatórios, que não alcançam as exigências impostas pela produção capitalista, ou por não consumirem nada ou por não consumirem adequadamente, ou seja, de modo insuficiente. É o excesso negativo da multidão. Eles são justamente os clientes do sistema penal por essa razão. Se a função essencial do cárcere hoje é de isolamento espacial desses indivíduos, o caráter seletivo da legislação penal se torna vítreo. É essa parte da multidão, esse excesso negativo, que deve ser retirado do meio social para que não

\footnotetext{
36 Ibidem, p. 109.

${ }^{37}$ Ibidem, p. 114.

38 Ibidem p. 115.
} 
possa contaminar a parte restante; sua inutilidade deve ser eliminada e o modo mais eficaz de fazê-lo é por meio da anulação de sua existência no espaço social, já que a partir do momento em que se isola um indivíduo dentro das paredes do cárcere sua existência torna-se fantasmática, imperceptível ao todo social. O preso encontra no cárcere sua supressão identitária, onde deixa de ser indivíduo e passa a ser refugo, transmuta-se de ser social singular e torna-se mero número das estatísticas carcerárias.

As subclasses, os pobres, os moradores do gueto. São esses os principais clientes do cárcere, justamente pela impropriedade ou insuficiência de seu consumo. A gestão do sistema penal é, portanto, administração da miséria, não mais com o intento de reformá-la e constituir uma mão de obra aproveitável e capaz de um consumo prudente, mas com o intento de periferizar, de marginalizar, de excluir uma parcela da população que então se tornou inútil para a atual conformação do modo de produção capitalista, prescindível de mão de obra farta em razão de sua acentuada produtividade possibilitada pelo vigoroso desenvolvimento tecnólogico e pela abundância de produção de valor por meio do trabalho imaterial.

A prisão transformou-se assim em forma de governo desse excesso negativo, parcela de indivíduos que deve sofrer determinada medida de controle social por extrapolar os moldes ideais da totalidade.

O excesso negativo é representado como um conjunto de subjetividades que excedem a lógica "governamental", uma vez que acentuam a contradição entre uma cidadania social baseada no trabalho e uma esfera produtiva que tem cada vez menos necessidade de trabalho vivo ${ }^{39}$.

A multidão congloba em sua totalidade abstrusa, pois, esse excesso negativo - o refugo humano - enquanto expressiva parcela populacional que não se enquadra nas conformidades da medida de cidadania. Um complexo de indivíduos que escapa às redes da governamentalidade capitalista.

Isto ocorre porque na atual sociedade as dinâmicas de inclusão social ainda colocam-se como mediação do trabalho entendido como emprego, como atividade desempenhada em tempo pleno, estável, garantida e contínua, em que essa medida

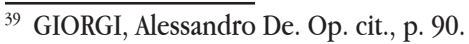


determina a titularidade dos direitos de cidadania. Por outro lado, a dinamicidade do modo de produção contemporâneo acaba por emergir por meio de uma nova estruturação que se funda justamente na precarização e na redução do trabalho, o que acaba por multiplicar esse excesso negativo. Em outras palavras, a acessibilidade à condição de cidadão, à renda, à integração social e à própria existência digna do ser subordinam-se ao preenchimento de um requisito que progressivamente tornase exíguo na materialidade pós-fordista ${ }^{40}$.

Surgem, portanto, novas coordenadas para orientar um novo conjunto de estratégias repressivas e de controle social que paralelamente à transição do fordismo ao pós-fordismo caracterizam uma transição do "Estado Social" ao "Estado Penal". Nesse sentido, Di Giorgi afirma que

No fundo, o que examinamos não é outra coisa senão a progressiva centralidade alcançada pelo cárcere, isto é, pelo dispositivo disciplinar par excellence na gestão da nova força de trabalho e dos grupos sociais marginais, grupos que, por sua vez, se ampliam cada vez mais em consequência do aumento do desemprego, da precarização do trabalho e do empobrecimento de massa que se seguiram à reestruturação do welfare ${ }^{41}$.

O que marca, pois, a nova prática penal não é a constituição de um dispositivo disciplinar que reproduz em seus confluxos uma relação de saber-poder como processo de individualização pontual e precisa, mas que, ao contrário, procura esvaziar esse conteúdo. O controle social do excesso negativo não se opera mais por meio de dispositivos que subjetivam, mas que vigiam, limitam e neutralizam.

As determinações concretas da multidão, as suas características constitutivas, os seus possíveis comportamentos, as interações às quais pode dar vida, as formas de cooperação que constantemente alimenta, escapam a qualquer definição rigorosa por parte dos aparelhos de controle. Esta condição de não-saber qualifica os dispositivos de controle e os orienta para uma função de supervisão, de limitação do acesso, de neutralização e de contenção do excesso ${ }^{42}$.

Por essa razão é que o encarceiramento em massa - facilmente detectável em uma rápida análise dos dados estatísticos da população carcerária da maioria dos países - não é um fenômeno anômalo ou descontextualizado e muito menos

\footnotetext{
${ }^{40}$ Ibidem, p. 90.

${ }^{41}$ GIORGI, Alessandro De. A miséria governada através do sistema penal. Tradução de Sérgio Lamarão. Rio de Janeiro: Revan, 2006, p. 97.

${ }^{42}$ Ibidem, p. 97
} 
corresponde ao estatuto de reflexo de um efetivo aumento da violência e da criminalidade. $\mathrm{O}$ aumento da população carcerária é uma decorrência lógica do aumento da população enquanto força de trabalho excedente; a criminalidade, portanto, não deve ser entendida sob um consequencialismo causal e simplista, mas como um sintoma de uma totalidade capitalista em crise por força de suas contradições internas estruturais e em constante luta pela sua manutenção.

\section{DISPOSITIVO, HOMO SACER E ESTADO DE EXCEÇÃO}

Toda essa nova forma de organizar a vida em si é determinada pelos dispositivos contemporaneos. No sentido agambeano, o dispositivo é todo o mecanismo que possibilita operar sobre a totalidade da vida dos indivíduos processos de vigilância e controle social, reestruturando novas formas de pensar, agir e viver. $\mathrm{O}$ dispositivo é

Qualquer coisa que tenha de algum modo a capacidade de capturar, orientar, determinar, interceptar, modelar, controlar e assegurar os gestos, as condutas, as opinióes e os discursos dos seres viventes. Não somente, portanto, as prisões, os manicômios, o Panóptico, as escolas, a confissão, as fábricas, as disciplinas, as medidas jurídicas e etc., cuja conexão com o poder é num certo sentido evidente, mas também a caneta, a escritura, a literatura, a filosofia, a agricultura, o cigarro, a navegação, os computadores, os telefones celulares e por que não - a própria linguagem que talvez é o mais antigo dos dispositivos, em que há milhares e milhares de anos um primata provavelmente sem se dar conta das consequências que se seguiriam - teve a inconsciência de se deixar capturar ${ }^{43}$.

O que caracteriza o dispositivo é que ele realiza um processo de produção de subjetividades. O dispositivo produz, portanto, saberes, que são absorvidos pelo sujeito, empreendendo a construção de uma identidade subjetiva que encontra em meio a estes saberes sua própria verdade. Ele é criador de saberes, na medida em que produz subjetividades; ao mesmo tempo, é mecanismo de controle, pois ao produzir saberes específicos, incute sutilmente peculiaridades, formando identidades pré-determinadas.

$\mathrm{Na}$ sociedade disciplinar - aquela que se conheceu ao longo do processo

43 AGAMBEN, Giorgio. O que é o contemporâneo? E outros ensaios. Tradução de Vinícius Nicastro Honesko. Chapecó: Argos, 2009, p. 40, 41. 
de acumulação primitiva de capital e da gênese e posterior declínio do modo de produção fordista - Foucault demonstrou que os dispositivos objetivavam a criação de corpos dóceis e produtivos que, mesmo submetidos à uma série de discursos, exercícios e saberes, assumiam sua identidade e sua liberdade subjetiva dentro do próprio processo de assujeitamento. Mas Agamben preconiza que na atual fase do capitalismo os dispositivos

\begin{abstract}
Não agem tanto mais pela produção de um sujeito quanto por meio de processos que podemos chamar de dessubjetivação. Um momento dessubjetivante estava certamente implícito em todo processo de subjetivação, e o Eu penitencial se constituía, havíamos visto, somente por meio da própria negação; mas o que acontece agora é que os processos de subjetivação e processos de dessubjetivação parecem tornar-se reciprocamente indiferentes e não dão lugar à recomposição de um novo sujeito a não ser de forma larvar, e por assim dizer, espectral. Na não-verdade do sujeito não há mais de modo algum a sua verdade ${ }^{44}$.
\end{abstract}

Essa nova forma estratégica dos dispositivos surge gradualmente como resultado de uma nova forma de organização da vida e estruturação do poder soberano. Para Foucault, a soberania evidenciava-se pela fórmula "fazer morrer e deixar viver". No entanto, a partir do século XVII, quando o zelo pelo vida e saúde dos súbitos passam a ser cada vez mais importantes nos mecanismos e cálculos estatais, o poder soberano transmuta-se paulatinamente naquilo que Foucault intitularia de biopoder. A antiga prerrogativa de fazer morrer e deixar viver dá espaço para uma

fórmula inversa em que "fazer viver e deixar morrer" passa a caracterizar a biopolí-

${ }^{44}$ Ibidem, p. 47. 
tica moderna $a^{45}$.

Agora essa tecnologia disciplinar, sob estratégias e técnicas diversas, é ampliada para o vasto domínio da vida, operando um novo poder direcionado à gestão de condutas e de governo sobre todos os processos da vida. Transforma-se o poder soberano de "deixar viver e fazer morrer" em um poder de "deixar morrer e fazer viver". Nesse sentido, Agamben afirma que

Pode-se dizer, aliás, que a produção de um corpo biopolítico seja a contribuição original do poder soberano. A biopolítica é, nesse sentido, pelo menos tão antiga quanto a exceção soberana. Colocando a vida biológica no centro de seus cálculos, o Estado moderno não faz mais, portanto, do que reconduzir à luz o vínculo secreto que une o poder à vida nua, reatando assim (segundo uma tenaz correspondência entre moderno e arcaico que nos é dado verificar nos âmbitos mas diversos) com o mais imemorial dos arcana imperii ${ }^{46}$.

\section{É premente delinear que os contornos dessa biopolítica partem da gestão}

\footnotetext{
${ }_{45}$ AGAMBEN, Giorgio. O que resta de Auschwitz: o arquivo e a testemunha (Homo Sacer III). Tradução de Selvino J. Assmann. São Paulo: Boitempo, 2008, p. 88. Esse paradoxo da soberania aparece pela primeira vez no curso do Collège de France d 1976: "[...] uma das mais maciças transformações do direito político do século XIX consistiu, não digo exatamente em substituir, mas em completar esse velho direito de soberania - fazer morrer ou deixar viver - com outro direito novo, que não vai apagar o primeiro, mas vai penetrá-lo, perpassa-lo, modifica-lo, e que vai ser um direito, ou melhor, um poder exatamente inverso: poder de 'fazer' viver e de 'deixar' morrer. O direito de soberania é, portanto, o de fazer morrer ou de deixar viver. E depois, este novo direito é que se instala: o direito de fazer viver e de deixar morrer. (FOUCAULT, Michel. Em defesa da sociedade: curso no Collège de France (1975-1976). Tradução de Maria Ermantina Galvão. São Paulo, Martins Fontes, 1999, p. 287). Acrescenta-se a isso que muito provavelmente Foucault já havia percebido como os aspectos mais agressivos da disciplinaridade estavam aos poucos sendo substituídos por outros paradigmas de gestão populacional (a governabilidade biopolítica, diferente da tanatopolítica disciplinar característica dos sécs. XVI até o início do séc. XX). Foucault não abandona a noção de disciplina, é claro, mas parece perceber como os dispositivos disciplinares de docilização passam a ser gradualmente reconfigurados pela "arte de governar" para uma finalidade mais afeita à gestão e ao controle, como já apontamos com Deleuze e como bem acena o próprio Foucault no curso do Collège de France de 1978: "Desde o século XVIII, vivemos na era da governamentalidade. Governamentalização do Estado, que é um fenômeno particularmente astucioso, pois se efetivamente os problemas da governamentalidade, as técnicas de governo se tornaram a questão política fundamental e o espaço real da luta política, a governamentalização do Estado foi o fenômeno que permitiu ao Estado sobreviver. Se o Estado é hoje o que é, é graças a esta governamentalidade, ao mesmo tempo interior e exterior ao Estado. São as táticas de governo que permitem definir a cada instante o que deve ou não competir a o Estado, o que é público ou privado, o que é ou não estatal, etc.; portanto o Estado, em sua sobrevivência e em seus limites, deve ser compreendido a partir das táticas gerais da governamentalidade. Talvez se pos$\mathrm{sa}$, assim de maneira global, pouco elaborada e portanto inexata, reconstruir as grandes formas, as grandes economias de poder no Ocidente, em primeiro lugar, o Estado de justiça, nascido em uma territorialidade de tipo feudal e que corresponderia grosso modo a uma sociedade da lei; em segundo lugar, o Estado administrativo, nascido em uma territorialidade de tipo fronteiriço nos séculos XV-XVI e que corresponderia a uma sociedade de regulamento e de disciplina; finalmente, um Estado de governo que não é mais essencialmente definido por sua territorialidade, pela superfície ocupada, mas pela massa da população, com seu volume, sua densidade, e em que o território que ela ocupa é apenas um componente. Este Estado de governo que tem essencialmente como alvo a população e utiliza a instrumentalização do saber econômico, corresponderia a uma sociedade controlada pelos dispositivos de segurança." (FOUCAULT, Michel. A Governamentalidade in: Microfísica do Poder. Tradução de Roberto Machado. Rio de Janeiro: Edições Graal, 1979, p. 292, 293, grifo nosso).

${ }^{46}$ AGAMBEN, Giorgio. Homo Sacer: o poder soberano e a vida nua I. Tradução de Henrique Burigo. 2. ed. Minas Gerais: Ed. da UFMG, 2014, p. 14.
} 
da vida orientando-se essencialmente pelo binômio inclusão/exclusão. A escolha do poder soberano sobre fazer viver e deixar morrer implica no poder sobre a vida nua; uma vida que é incluída para ser excluída. Legitima-se assim ao Estado contemporâneo a defesa de direitos fundamentais por meio de uma lógica defensivista de exclusão do outro enquanto considerado como uma ameaça em potencial.

Para Agamben a vida nua está vinculada essencialmente à forma do bomo sacer.

Uma obscura figura do direito romano arcaico, na qual a vida humana é incluída no ordenamento unicamente sob a forma de sua exclusão (ou seja, de sua absoluta matabilidade). [.... O espaço da vida nua, situado originariamente à margem do ordenamento, vem progressivamente a coincidir com o espaço político, e exclusão e inclusão, externo e interno, bíos e zoé, direito e fato entram em uma zona de irredutível distinção ${ }^{47}$.

A etimologia do bomo sacer origina-se do direito romano arcaico, em que alguns historiadores quiseram enxergar nela uma espécie de pena do direito criminal romano desse período, figura pela qual a lei expulsava um sujeito da jurisdição humana, obrigando-o que fosse sagrado à determinada divindidade. Não obstante essa abordagem incompleta - ou talvez até mesmo equivocada - conceituar a figura do homem sacro com precisão exigiria ir muito além dessa definição, vertendo uma profícua mas extensa digressão histórica no momento inoportuna.

Apesar desse processo de sacralização, não era ilícito matar o homem sacro; a violação da coisa sacra era vedada, mas a profanação da sacralidade do homem não. O bomo sacer não era sacrificável na medida em que não era possível oferecer aos deuses algo que já estava sob sua posse; ao mesmo tempo, o assassínio do homem sacro era também impunível por estar alocado além dos limites da jurisdição terrenal.

A sacratio configura uma dupla exceção, tanto do ius humanum quanto do ius divinum, tanto do âmbito religioso quanto do profano. A estrutura topológica, que esta dupla exceção desenha, é aquela de uma dúplice exclusão e de uma dúplice captura, que apresenta mais do que uma simples analogia com a estrutura da exceção soberana $^{48}$.

A condição de bomo sacer é portanto definida não apenas pela hipotética

\footnotetext{
${ }^{47}$ Ibidem, p. 16.

${ }^{48}$ Ibidem, p. 84 .
} 
ambivalência oriunda da sacralidade que lhe é imanente, mas sobretudo pelo caráter peculiar da exclusão dupla na qual se encontra aprisionado e da violência à qual está exposto. A impunidade pela violência que pode ser exercida em relação a ele não é classificável nem como homicídio e nem como sacrifício, nem como execução de uma pena e nem como sacrilégio. Ao excepcionar-se das formas sancionadas presentes nos direitos humano e divino, abre-se um âmbito do agir humano que não é da profanação e nem do tornar sagrado. Esse espaço é onde impera apenas a decisão soberana, ato que por meio do estado de exceção suspende a lei e nele implica a vida nua ${ }^{49}$.

O estado de exceção é, dessarte, o espaço de gestão dessa vida nua. É no âmbito da vida nua que se impõe o fenômeno da suspensão da norma; o estado de exceção permite ao ordenamento jurídico manter-se em íntima relação com aquilo que excluiu, mantendo a vida nua em sempiterna relação com o poder que a baniu.

A exceção é uma espécie de exclusão. Ela é um caso singular, que é excluído da norma geral. Mas o que caracteriza propriamente a exceção é que aquilo que é excluído não está, por causa disto, absolutamente fora da relação com a norma; ao contrário, esta se mantém em relação com aquela na forma da suspensão. A norma se aplica à exceção desaplicando-se, retirando-se desta. O estado de exceção não é, portanto, o caos que precede a ordem, mas a situação que resulta da sua suspensão. Nesse sentido, a exceção é verdadeiramente, segundo o étimo, capturada fora (ex-capere) e não simplesmente excluída ${ }^{50}$.

O que acontece no estado de exceção é a criação de uma situação que não pode ser delineada como uma situação de fato já que é criada pela simples suspensão da norma; ao mesmo tempo, não pode ser enquadrada como uma situação de direito, ainda que seja possível sobre ela a vigência da lei. Portanto, entre elas é estabelecido um limiar - o estado de exceção - entre fato e direito, natural e jurídico. E neste limiar, no espaço da vida nua, o soberano transita livremente ${ }^{51}$.

O corpo biopolítico, que constitui o novo sujeito político fundamen-

${ }^{49}$ Ibidem, p. 84.

${ }^{50}$ Ibidem, p. 24.

${ }^{51}$ Como explica Agamben: "[...] o estado de exceção apresenta-se como a abertura de uma lacuna fictícia no ordenamento, com o objetivo de salvaguardar a existência da norma e sua aplicabilidade à situação normal. A lacuna não é interna à lei, mas diz respeito à sua relação com a realidade, à possibilidade mesma de sua aplicação. É como se o direito contivesse uma fratura essencial entre o estabelecimento da norma e sua aplicação e que, em caso extremo, só pudesse ser preenchida pelo estado de exceção, ou seja, criando-se uma área onde essa aplicação é suspensa, mas onde a lei, enquanto tal, permanece em vigor. (AGAMBEN, Giorgio. Estado de exceção. Tradução de Iraci D. Poleti. 2. ed. São Paulo: Boitempo, 2004, p. 48,49). 
tal, não é uma quaestio facti (como, por exemplo, a identificação de um certo corpo biológico) nem uma quaestio iuris (a identificação de uma certa norma a ser aplicada), mas a aposta de uma decisão política soberana, que opera na absoluta indiferenciação entre fato e direito ${ }^{52}$.

Erigido sobre o fundamento de proteção da vida e garantia de direitos, o poder soberano enceta assim a prerrogativa de valer-se da exceção; aplica a norma sobre a exceção, desaplicando-a; insere a vida nua no âmbito do ordenamento jurídico para que ela possa ser efetivamente excluída. O que se verifica, pois, é a faculdade absoluta atribuída ao poder soberano de suprimir direitos e garantias por meio da exceção e de colocar-se, legalmente, fora da lei. Nesse espaço de suspensão de direitos não há resistência para a perpetração de violências, estabelecendo-se o estado de exceção como estrutura-jurídico política padrão.

\section{A NOVA LÓGICA ATUARIAL NA SOCIEDADE DE RISCO}

O sistema penal moderno baliza-se, pois, sob uma nova tendência de contenção e vigilância daqueles que se opõem como um risco para a sociedade, ou seja, que se colocam de alguma forma como óbice para a perenização da ordem social dominante. A prisão, portanto, projeta-se orientada por uma lógica atuarial, produto da própria essência do estado de exceção como aspecto imanente da biopolítica moderna.

O atuarialismo, por definição, pauta-se no cálculo e na avaliação probabilística dos riscos. Dessa forma, instaura uma postura que se preocupa muito mais com a minimização dos problemas atinentes à criminalidade e muito menos com a busca de alguma medida de justiça.

A postura atuarial calcula riscos, é cautelosa e probabilística, e não se preocupa com causas, mas com probabilidades, não com justiça mas com minimização dos danos, não busca livrar o mundo da criminalidade, mas um mundo em que tenham sido postas em prática as melhores rotinas de limitação de perdas; não uma utopia mas uma série de paraísos murados num mundo hostil ${ }^{53}$.

Essa lógica atuarial acaba por escamotear a existência real de criminalidade,

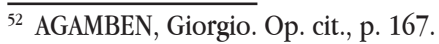

53 YOUNG, Jock. A sociedade excludente: exclusão social, criminalidade e diferença na modernidade recente. Tradução de Renato Aguiar. Rio de Janeiro: Revan, 2002, p. 105.
} 
desconsiderando-a como fator relevante para a aplicação do discurso jurídico-ideológico. Além disso, ela acaba por retirar o significado moral dos relacionamentos humanos, desembarançando-os de julgamentos morais e destituindo-os de sua significância moral; o atuarialismo é, dessa forma, moralmente neutro ${ }^{54}$, possibilitando a realização de um discurso em que o que importa essencialmente é a supressão ou a amenização dos riscos.

É evidente que a determinação do que vem a ser um risco ou não para a sociedade deriva de um constructo ideológico reproduzido pelos mais variados dispositivos. Seja pela mídia, pelo discurso jurídico-penal ou até mesmo pelo ensino escolar, há a propagação de discursos ideológicos que reproduzem uma lógica completamente atrelada à manutenção da totalidade capitalista. Desse modo, os riscos são determinados como tais apenas enquanto circunstâncias que se tornam riscos para a permanência estável dessa totalidade orgânica.

Em contínuo, no que toca à racionalidade do discurso jurídico-penal contemporâneo, Di Giorgi aduz que o que o orienta é o conceito de risco.

As novas estratégias penais se caracterizam cada vez mais como dispositivos de gestão do risco e de repressão preventiva das populações consideradas portadoras desse risco. Não se trata de aprisionar criminosos perigosos individuais, isto é, de neutralizar fatores de risco individual, mas sim de gerir, ao nível de populações inteiras, uma carga de risco que não se pode (e, de resto, não se está interessado) em reduzir. A racionalidade que estamos descrevendo não é disciplinar, e sim atuarial 55 .

Desse modo, o cárcere atuarial projeta-se como forma de administração do risco e de controle social daqueles que poderiam ser considerados vetores desse risco. O termo risco deve ser entendido, por conseguinte, não como efetiva criminalidade ou periculosidade, mas como uma conduta que escapa às determinações da lógica governamental que se orientam pela manutenção das constâncias do modo de produção e dos interesses daqueles que são por ele privilegiados. Nesse sentido, Di Giorgi afirma que

O recrutamento da população carcerária ocorre com base na identificação (mas melhor seria dizer "invenção") das classes de sujeitos consideradas produtoras de risco, potencialmente desviantes e perigosas para a ordem constituída. Assim, não são mais tanto as características individuais dos sujeitos que constituem o pressuposto (e ao

${ }^{54}$ Ibidem, p. 106.

55 GIORGI, Alessandro De. Op. cit., p. 97. 
mesmo tempo o objeto) das estratégias de controle, mas sim aqueles indícios de probabilidades que permitem reconduzir determinados sujeitos a classes perigosas específicas. Isso significa, concretamente, que categorias inteiras de indivíduos deixam virtualmente de cometer crimes para se tornarem, elas mesmas, crime. As determinações peculiares dos sujeito, que as tecnologias disciplinares pretendiam misturar, dobrar e transformar, são substituídas por agregados estatísticos que oferecem às agências da repressão a nova linha-guia para a seleção da população carcerária. A atuarialização do controle se materializa assim num conjunto de práticas que desestruturam os indivíduos e os substituem por construções artificiais que, por sua vez, alimentam práticas de contenção preventiva ${ }^{56}$.

Há, portanto, por meio do cárcere atuarial, um esvaziamento do indivíduo, em que as subjetividades identitárias do ser lhe são completamente despojadas e são substituídas por determinações artificiais que desconsideram o indivíduo enquanto sujeito, erigindo novas categorizações de significação que o alçam à simples identificação entre indivíduo de risco ou de não risco.

O risco, evidentemente, por sua própria definição, estará sempre refletido no semblante daqueles que não podem ser subsumidos à razão governamental orientada pela lógica da totalidade singular e significada pela ordem simbólica do capital. Por essa razão a clientela do sistema penal estará sempre previamente selecionada e a racionalidade do discurso jurídico-penal nunca poderá se realizar de outra forma que não sob a forma de seu fetichismo.

\section{CONCLUSÃO}

Os efeitos do cárcere atuarial resultante dessa nova lógica da sociedade de risco - um nome que condensa no campo penal os efeitos de uma sociedade permeada pelo controle, pelo desempenho e pelo espetáculo -

acabam por dessignificar os sujeitos, definindo uma desconfiança universal que impede o reconhecimento mútuo entre os sujeitos enquanto parte de uma mesma força de trabalho. Essa é uma das razões pela qual o sujeito que é inserido no cárcere torna-se refugo humano. Em uma sociedade em que o risco é dado como sinônimo de perigo o indivíduo que se torna um risco social é negado pelo corpo social e deve ser afastado na medida em que interfere na "paz" e na "ordem" estabelecida. O que

${ }^{56}$ Ibidem, p. 98,99. 
ocorre efetivamente, porém, é que esse risco geralmente é composto por um conjunto abstruso de subjetividades - a multidão - que escapa à governamentalidade capitalista, e que por essa razão deve ser supervisionada, contida e minimamente controlada, na medida em que pode vir a se transformar num entrave à ordem instituída. Para evitar esse contraefeito, esse excesso negativo é "inserido" na ordem social, para que possa então ser "excluído", fechando-se o espelho binomial da relação inclusão/exclusão do estado de exceção biopolítico.

Desse modo, o risco constitui-se hoje como elemento central e engendrador da dogmática penal, ao mesmo tempo estabelecendo-se como seu objeto, mas também como seu elemento legitimador; a diminuição dos riscos, a minimização dos danos e a manutenção da paz ordenada erigem-se como diretrizes basilares do dicurso jurídico-penal atual. No entanto, essa articulação autolegitimante possui como escopo a contenção do risco, mas apenas enquanto elemento que afronta a própria ordem constituída. Nesse sentido, os elementos que escapam à lógica do capital (valor), ou que não correspondem minimamente às exigências do espetáculo e do desempenho, devem ser isolados espacialmente para que possam ser encampados no seu âmbito de controle - inclusão/exclusão - já que a subjetividades múltiplas e abstrusas da multidão - no que tange ao seu excesso negativo - fogem ao conceito-limite de cidadania, dificultando e em alguns casos até mesmo impossibilitando um controle gerencial dessa coletividade singular.

O que acontece, portanto, ao inserir esses indivíduos - o "outro", "refugo humano", "excesso negativo" inadequado ao modo de produção capitalista contemporâneo - no cárcere é um movimento duplo, em que o sujeito é incluído, enquanto é encampado dentro da vigência da lei, mas é excluído, já que expulso do meio social e atirado aos novos depositários de lixo humano da modernidade, as prisões. Nesses espaços, o sujeito é dessubjetivado, tornando-se identitariamente invisível; sua existência é esvaziada e dessignificada, mas acima de tudo, absolutamente neutralizada e controlada. Dentro dos espaços carcerários, a vigência do significado da norma pode então ser suspensa a qualquer tempo sem embaraços diante desses "não-sujeitos" despojados de sua identidade. Por essa razão é forçoso dizer que há um denso e intrincado paralelo entre o encarcerado de hoje e o bomo sacer agambeano em que a similitude é mais real e inquietante do que a teoria deixa transparecer.

Dessa forma, somos colocados diante de um paradigma teórico e prático completamente diferente daquele que estávamos habituados a apreender nas abor- 
dagens foucaltianas do discurso e da prática penal, de tal forma que, ao longo da presente análise, nos propusemos a elaborar uma perspectiva do fenômeno jurídico-penal que o abordasse de maneira dialética, considerando seu desenvolvimento material histórico e lógico rumo a uma transformação pós-disciplinar e pós-foucaltiana que nos põe diante de uma nova paralaxe da problemática penal. Esse novo ponto de vista, que entendemos mais habilitado a compreender de modo efetivo e conceitual o fenômeno investigado, nos permite a composição de um novo conjunto de abordagens e possibilidades mais atuais e aptas a lidar com a emaranhada problemática da crise prático-discursiva dos mecanismos e dispositivos penais.

\section{REFERÊNCIAS}

AGAMBEN, Giorgio. Estado de exceção. Tradução de Iraci D. Poleti. 2. ed. São Paulo: Boitempo, 2004.

AGAMBEN, Giorgio. Homo Sacer: o poder soberano e a vida nua I. Tradução de Henrique Burigo. 2. ed. Minas Gerais: Ed. da UFMG, 2014.

AGAMBEN, Giorgio. O que é o contemporâneo? E outros ensaios. Tradução de Vinícius Nicastro Honesko. Chapecó: Argos, 2009.

AGAMBEN, Giorgio. O que resta de Auschwitz: o arquivo e a testemunha (Homo Sacer III). Tradução de Selvino J. Assmann. São Paulo: Boitempo, 2008.

AGUIAR, Roberto A. R. de. Direito, Poder e Opressão. São Paulo: Alfa-Omega, 1990, p. 98 .

BAUMAN, Zygmunt. Vidas desperdiçadas. Tradução de Carlos Alberto Medeiros. Rio de Janeiro: Zahar, 2005. p. 109.

BAUMAN, Zygmunt. Globalização: as consequências humanas. Tradução de Marcos Penchel. Rio de Janeiro: Zahar, 1999.

BYUNG-CHUL, Han. Sociedade do cansaço. Tradução de Enio Paulo Giachini. Petrópolis, RJ: Vozes, 2015.

DORIA, Kim; JINKINGS, Ivana. 1917: o ano que abalou o mundo. São Paulo: Boi- 
tempo, 2017.

DEBORD, Guy. A sociedade do espetáculo. Tradução de Estela do Santos Abreu. Rio de Janeiro: Contraponto, 1997.

DELEUZE, Gilles. Post-scriptum sobre as sociedades de controle. In: DELEUZE, Gilles. Conversações. Tradução de Peter Pál Pebart. São Paulo: Ed. 34, 1992.

FOUCAULT, Michel. Vigiar e punir: nascimento da prisão. Tradução de Raquel Ramalhete. 38. ed. Rio de Janeiro: Vozes, 2010.

FOUCAULT, Michel. A Governamentalidade. In: FOUCAULT, Michel. Microfísica do Poder. Tradução de Roberto Machado. Rio de Janeiro: Graal, 1979.

FOUCAULT, Michel. Em defesa da sociedade: curso no Collège de France (19751976). Tradução de Maria Ermantina Galvão. São Paulo, Martins Fontes, 1999.

FUKUYAMA, Francis. A história venceu: Francis Fukuyama joga a toalha. Exame, São Paulo, 22. jan. 2016. Disponível em: < https://exame.abril.com.br/revista-exame/a-historia-venceu/> . Acesso em: 07 dez. 2017.

FUKUYAMA, Francis. Para filósofo, "fim da história" pode acontecer - de novo. Exame, São Paulo, 30 jun. 2016. Disponível em: < https://exame.abril.com.br/economia/ para-filosofo-o-fim-da-historia-pode-acontecer-de-novo/> . Acesso em 07 dez. 2017.

FUKUYAMA, Francis. The end of history and the last man. Nova York, EUA: The Free Press, 1992.

GIORGI, Alessandro De. A miséria governada através do sistema penal. Tradução de Sérgio Lamarão. Rio de Janeiro: Revan, 2006.

GOFFMAN, Erving. Prisões, manicômios e conventos. Tradução de Duarte Moreira Leite. São Paulo: Perspectiva, 1974.

GOMIDE, Bruno Barretto (Org.). Escritos de outubro. Tradução Paula Almeida et al. São Paulo: Boitempo, 2017.

KARATANI, Kojin. Structure of world history: from modes of production to modes 
of exchange. Traduzido por Michael K. Bourdaghs. Durham; Londres: Duke University Press, 2014.

KASHIURA JR., Celso Naoto. Crítica da igualdade jurídica: contribuição ao pensamento jurídico marxista. São Paulo: Quartier Latin, 2009.

KOJÈVE, Alexandre. Introdução à leitura de Hegel. Tradução de Estela dos Santos Abreu. Rio de Janeiro: Contraponto, 2014.

LACAN, Jacques. O seminário, livro 23: o sinthoma (1975-1976). Tradução de Sergio Laia. Rio de Janeiro: Jorge Zahar ed. 2007.

LOSURDO, Domenico. Guerra e revolução: o mundo um século após outubro de 1917. Tradução de Ana Maria Chiarini e Diego Silveira Coelho Ferreira. São Paulo: Boitempo, 2017.

MARX, Karl. Grundrisse: manuscritos econômicos de 1857-1858: esboços da crítica da economia política. Tradução de Mário Duayer e Nélio Schneider. São Paulo: Boitempo; Rio de Janeiro: Ed. da UFRJ, 2011.

MASSIMO, Pavarini; MELOSSI, Dario. Cárcere e fábrica: as origens do sistema penitenciário (séculos XVI-XIX). Tradução de Sérgio Lamarão. Rio de Janeiro: Revan, 2006.

MENEZES, Djacir. Motivos alemães: filosofia, hegelianismo, marxologia, polêmica. Rio de Janeiro: Cátedra; Brasília, INL, 1977.

NETTO, José Paulo. Introdução ao estudo do método de Marx. São Paulo: Expressão Popular.

MIÉVILLE, China. Outubro: história da Revolução Russa. Tradução de Heci Regina Candiani. São Paulo: Boitempo, 2017.

NEGRI, Antonio. Cinco lições sobre Império. Tradução de Alba Olmi. Rio de Janeiro: DP\&A, 2003. (Coleção Política das Multidões).

ROSDOSLKY, Roman. Gênese e estrutura de O Capital de Karl Marx. Tradução de 
César Benjamin. Rio de Janeiro: EDUERJ; Contraponto, 2001.

TRÓTSKI, Leon. A Revolução de Outubro. 2. ed. Tradução de Daniela Jinkings et al. São Paulo: Boitempo, 2017.

YOUNG, Jock. A sociedade excludente: exclusão social, criminalidade e diferença na modernidade recente. Tradução de Renato Aguiar. Rio de Janeiro: Revan, 2002.

ZAFFARONI, Eugenio Rául. Em busca das penas perdidas: a perda da legitimidade do sistema penal. Tradução de Vania Romano Pedrosa e Amir Lopez da Conceição. Rio de Janeiro: Revan, 1991.

ZIZEK, Slavoj. The sublime object of ideology. Londres, Inglaterra; Nova York, EUA: Verso Books, 2008.

Recebido em: 08 de fevereiro de 2016 Aceito em: 18 de julbo de 2018 